\title{
The Taiga Bean Goose Anser fabalis fabalis in Latvia: occurrence, origin and hunting
}

\author{
Hakon Kampe-Persson ${ }^{1 *}$, Dmitrijs Boiko² \\ ${ }^{1}$ Pulman̦i, Glūdas pagasts, Jelgavas novads, Nākotne LV-3040, Latvia \\ ${ }^{2}$ Institute of Biology, University of Latvia, Miera 3, Salaspils LV-2169, Latvia \\ ${ }^{\star}$ Corresponding author, E-mail: kampepersson@hotmail.com
}

\begin{abstract}
The aim of this study was to fill knowledge gaps regarding occurrence, origin and hunting of the Taiga Bean Goose Anser fabalis fabalis in Latvia. Field observations during the period 1 January 2011 - 20 May 2019 showed that up to at least 550 individuals from the central sub-population made stop-overs in westernmost Latvia in early spring, usually during the last ten days of February. Up to at least 1750 individuals from the eastern sub-population arrived about one month later and made stop-overs in eastern Latvia. Few individuals were reported staging in autumn. A hunting bag study, where hunters submitted images of bean geese they had shot, was launched in 2014 . The proportion of the hunted geese reported by images was low in the first two years, but ranged from 9.5 to $12.4 \%$ during the following years. Based on this bag study, the number of Taiga Bean Geese hunted annually in the years $2014-2018$ was estimated to be $0-20$ birds.
\end{abstract}

Key words: East Baltic Sea flyway, hunting bag, Latvia, occurrence, origin, Taiga Bean Goose.

\section{Introduction}

The Taiga Bean Goose Anser fabalis fabalis (Latham, 1787) breeds in the boreal zone, often in aapa mires, from Scandinavia eastwards to western Siberia and uses four discrete flyways (Marjakangas et al. 2015). The western sub-population breeds along the border between Norway and Sweden, migrates through the western part of Sweden and winters in northern Jutland, Norfolk and Scotland. The central sub-population breeds in northern Sweden, northern Norway, northern and central Finland and in neighbouring parts of Russia. These geese stage in Sweden on their way to winter quarters in Scania and Denmark. Taiga Bean Geese breeding in the upper Pechora region and western parts of west Siberian lowlands are divided into two sub-populations depending on where they winter. One of them winters in north-eastern Germany and northwestern Poland and the other in south-eastern Kazakhstan, eastern Kyrgyzstan and north-western China.

The world population of Taiga Bean Geese has declined markedly during the last few decades. Numbers wintering in Europe declined from about 100000 individuals in the mid-1990-ies (Nilsson et al. 1999) to 63000 in 2009 (Fox et al. 2010) and 51500 in 2014 (Marjakangas et al. 2015). Birds wintering in Europe comprise almost the entire world population of this taxon, as only small numbers winter in Asia (Heinicke 2009). Due to this downward trend, first reported by Huyskens (1999), an International Action Plan was established for this taxon (Marjakangas et al. 2015). This Action Plan is the first flyway conservation plan for a taxon in decline, which is still open for hunting. It outlines the distribution, status and threats of the taxon and lays out the framework for action, including key actions to achieve the required results.

Due to failures to distinguish the Taiga Bean Goose from the more numerous Tundra Bean Goose Anser serrirostris rossicus (Buturlin, 1933), which often stages and winters in the same areas, the true distribution and numbers of Taiga Bean Geese are still uncertain in most countries (for references, see Marjakangas et al. 2015).

In Latvia, about 200 staging areas are used by geese, in both spring and autumn (Kampe-Persson 2010a and unpublished results). Hundreds of thousands of geese, mainly Tundra Bean Geese and European White-fronted Geese Anser albifrons albifrons (Scopoli, 1769), make stopovers in Latvia in spring, many of them for about one month. For the autumn-staging period, on the other hand, little is known about numbers and duration of stay. Staging geese in Latvia are not included in any national or regional monitoring programme, as are used in Sweden (Nilsson 2013; Kampe-Persson 2014). Two Latvian staging areas have, however, been quite regularly checked: the Nìca fields, the farmland area between Lake Pape and Nìca, in early spring and Svete flood-plain, at the confluence of the Rivers Svète and Lielupe, during the entire spring-staging period. About $85 \%$ of the other Latvian staging areas have been visited, at least once, by the first author during searches for Lesser White-fronted Geese (Kampe-Persson 2015).

In the International Action Plan for the Taiga Bean Goose (Marjakangas et al.2015), Latvia is listed as one of 15 
range states. However very few data are given for Latvia. The number and trend of staging Taiga Bean Geese in Latvia is given as unknown, although exceeding 1000 individuals, and the hunting bag is given as c. 300 Taiga Bean Geese annually in the years $2008-2013$. To reach the expectations of the Action Plan regarding the range states, much better knowledge is needed about the Taiga Bean Goose in Latvia.

The aim of this study was to fill knowledge gaps regarding occurrence, origin and hunting of the Taiga Bean Goose in Latvia.

\section{Materials and methods}

Description of the occurrence of Taiga Bean Geese in Latvia was based on observations of staging birds made during the period 1 January 2011 - 20 May 2019. Observations made by the first author and observations made by others and e-mailed to him were supplemented by data published on www.dabasdati.lv and www.latvijasputni.lv.

Recoveries and re-sightings in Latvia of Taiga Bean Geese marked on the breeding grounds were used to determine origin of birds staging in Latvia. Neck-collaring data of birds marked in other parts of the species' range were also checked for links between breeding grounds and Latvia.

Goose species that were hunted in Latvia were Taiga Bean Goose, Tundra Bean Goose, Greater White-fronted Goose Anser albifrons and Greylag Goose Anser anser. In the Latvian legislation however, Taiga and Tundra Bean Goose were not separated but both named Bean Goose Anser fabalis. The open season was 15 September - 30 November.

In 2014 - 2018, hunters in Latvia were asked to take photos of the head of the bean geese they shot and submit these images to the Latvian Hunters' Association. Even though far from all hunting parties responded, images were submitted from all parts of Latvia housing staging geese (Fig. 1). Due to the low numbers of images submitted in the first two years (Table 1), data for the years $2014-2016$ were pooled. The well-known difficulties to distinguish the two species make it unlikely that any images of surmised Taiga Bean Geese were withheld from submission. Determination of species in the submitted images was done by the authors.

\section{Results}

The available observations of spring-staging geese in Latvia showed large disparity among staging areas and years. The staging areas demonstrated the whole spectra from areas that had been frequently checked every year to areas from which only one flock had been reported. The commonly used method in situations like this, to establish the target species' proportion of the total number of geese by sampling as many flocks as possible and then multiplying the resulting proportion with the total number of geese to estimate the overall total number of individuals of the target species, is not applicable in this case. This is because the spring-staging pattern of the Taiga Bean Goose greatly differs, both in timing and distribution, from that of the Tundra Bean Goose and the Russian White-fronted Goose. Also, Taiga Bean Geese were often reported as either bean geese or unidentified grey geese. The available data set was therefore instead used to simply outline the general springstaging pattern of the Taiga Bean Goose.

Spring-staging Taiga Bean Geese in Latvia arrived in two migration waves. Birds in the first wave staged in

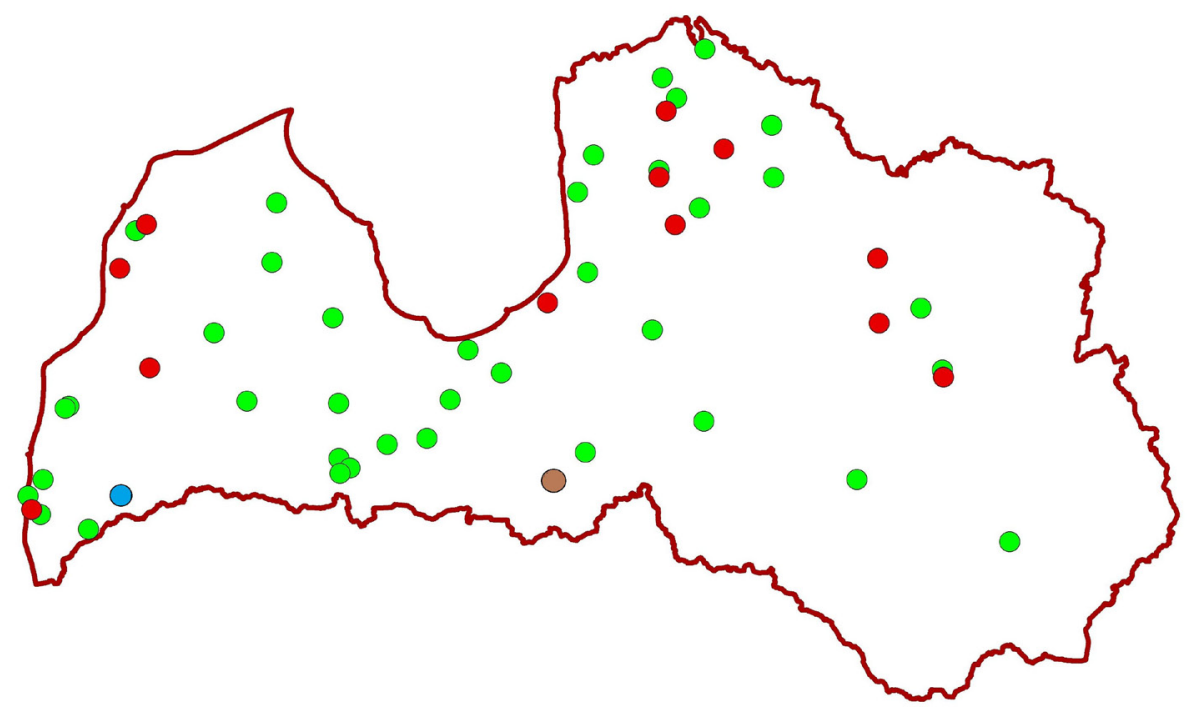

Fig. 1. Map depicting sites in Latvia where flocks of Taiga Bean Geese Anser fabalis fabalis numbering at least 100 individuals were recorded in spring in 2011 - 2019 (red dots), sites from where hunters submitted photos of hunted bean geese in $2014-2018$ (green dots), site of recovery of a Taiga Bean Goose originating from the breeding range of the central sub-population (blue dot) and site of recovery of a Taiga Bean Goose from a Swedish re-enforcement project (brown dot). 
Table 1. Number of hunted bean geese in Latvia in 2014 - 2018 that were reported by images to the Latvian Hunters' Association, number of hunted bean geese in Latvia in 2014 - 2018 (data provided by Valsts meža dienests / State Forest Service) and the proportion of the hunted bean geese that were reported by images. ${ }^{*}$, images of 49 of these 129 birds could not be used for species determination

\begin{tabular}{lccc} 
Year & $\begin{array}{c}\text { Number of hunted } \\
\text { reported by images }\end{array}$ & $\begin{array}{c}\text { Number of } \\
\text { hunted bean } \\
\text { geese }\end{array}$ & $\begin{array}{c}\text { Proportion of hunted reported by } \\
\text { images (\%) }\end{array}$ \\
\hline 2014 & 33 & 1213 & 2.7 \\
2015 & 22 & 1423 & 1.5 \\
2016 & 86 & 695 & 12.4 \\
2017 & 141 & 1238 & 11.4 \\
2018 & $129^{*}$ & 1356 & 9.5 \\
\hline
\end{tabular}

western Kurzeme, the westernmost part of Latvia, and those in the second wave in Latgale and Vidzeme, the eastern and northern parts of Latvia (Fig. 1).

Taiga Bean Geese were among the first geese that arrived in Latvia in spring and the first individuals were regularly recorded in Nica fields, the farmland area between Lake Pape and Nica, in the south-western corner of the country. Here, numbers usually built up to a peak within a week. At Užava lowlands, a farmland area situated further north, about $25 \mathrm{~km}$ south of Ventspils, peak numbers were recorded in the same week as at Nica fields. In early spring in years when there were snow-free fields in westernmost Latvia by the third week of February, peak counts were recorded during the last ten days of February. After peak numbers had been reached, no further observations were made in these staging areas that spring. As the arrival in spring was related to the availability of snow-free fields for feeding, the geese arrived later in years when the snow melted later. In the very late spring of 2013, flocks exceeding 100 individuals were also recorded in Kamārce meadows, about $5 \mathrm{~km}$ east of Ventspils and at Turlava, about $10 \mathrm{~km}$ north-east of Aizpute (Fig. 1). The highest total for these four sites during the study period was recorded in 2013, when 550 individuals were counted.

In Latgale and Vidzeme, all but two of the counts of at least 100 individuals were recorded during the last week of March or the first days of April. The two observations outside this time window were both made in 2011, 500 individuals at Umurga, $5 \mathrm{~km}$ east of Limbaži, on 5 March and 100 individuals at Velēna on 30 April (Dabas Dati). Besides the peak counts depicted on the map (Fig. 1), there were very few observations of Taiga Bean Geese in spring in these parts of the country. Occasionally, flocks numbering up to 30 birds were reported up to the second week of May. The two largest flocks, 1100 individuals at Lake Lubāns (Latvijas Putni) and 650 at Braslava, about $10 \mathrm{~km}$ west of Lake Burtnieks, were both recorded in 2016. The highest total for Latgale and Vidzeme during the study period was recorded in 2016, when 1750 individuals were counted.

In eastern Kurzeme, Latgale and Sēlija, i.e. between the staging regions described above, several staging areas housed more than 10000 staging geese in spring (KampePersson 2010a and unpublished results). Despite the fact that many of these areas were frequently checked, flocks exceeding 20 Taiga Bean Geese were never recorded in these parts of the country.

In autumn, few flocks of staging geese were ever reported and none involved more than four Taiga Bean Geese.

Two marked birds recovered in Latvia (Fig. 1) could be linked to the inbreeding grounds. Both birds originated from the range of the central population and were shot in

Table 2. Number of hunted grey geese Anser sp. and Taiga Bean Geese Anser fabalis fabalis, Tundra Bean Geese Anser serrirostris rossicus, White-fronted Geese Anser albifrons and Greylag Geese Anser anser in Latvia, 2011 - 2018. The number of Taiga Bean Geese in 2013 was taken from Marjakangas et al. (2015) and the numbers of Taiga Bean Geese in $2014-2018$ from this study. Other data were provided by Valsts meža dienests / State Forest Service. ${ }^{\star}, 183$ White-fronted Geese + Greylag Geese were not separated to species

\begin{tabular}{lccccc} 
Year & Grey geese & Taiga Bean & Tundra Bean & White-fronted & Greylag \\
\cline { 2 - 6 } 2011 & \multicolumn{7}{c}{} & 1373 & & \\
\hline 2012 & 1483 & c. 300 & 1939 & 324 & 221 \\
2013 & 1791 & 17 & 1196 & 400 & 178 \\
2014 & 2011 & 20 & 1403 & 388 & 200 \\
2015 & 1085 & 10 & 685 & 430 & 227 \\
2016 & 1924 & 0 & 1238 & $627^{*}$ & $580^{*}$
\end{tabular}


Latvia. One of them was neck-collared at Lake Vombsjön in southernmost Sweden on 9 November 1977 and shot at Kalēti on 20 September 1978 (Nilsson 1982). The breeding range origin for this bird was determined by the help of the life-histories of marked family members. The second bird was released as a gosling at Nornäs in the southernmost part of the Swedish breeding range on 3 July 1978 and shot at Vecsaule on 24 September 1978 (von Essen 1982). Another gosling, released at the same site the very same day, was shot outside Moscow on 3 October 1978. These goslings belonged to a re-enforcement project, using Greater Canada Geese Branta canadensis as foster parents (von Essen 1982). The main wintering area for birds from this project at that time was in the Foteviken area in southwesternmost Sweden (Kampe-Persson 2010b). These two first-calendar birds had probably gone astray after losing contact with their foster parents.

Among the submitted images, there were 139 Tundra Bean Geese and two Taiga Bean Geese in the years 2014 2016, 141 Tundra Bean Geese but no Taiga Bean Goose in 2017 and 79 Tundra Bean Geese and one Taiga Bean Goose in 2018. These proportions were used to calculate the total number of Taiga Bean Geese in each year's hunting bag in the years $2014-2018$ (Table 2). Pooling the samples from all five years $(n=362)$ and using the resulting proportion of Taiga Bean Geese $(0.83 \%)$ to calculate the total number of that taxon in each year's hunting bag in the years 2014 2018 should give a similar result (range $6-12$ ).

\section{Discussion}

The Taiga Bean Geese staging in spring in western Kurzeme and Latgale/Vidzeme, respectively, formed two separate groups. The first flocks in Latgale and Vidzeme were usually observed about four weeks after the last observation made in western Kurzeme, while only low numbers were ever seen between these two staging regions (this study).

The migration route along the East Baltic Sea coast used by Taiga Bean Geese in the 1870-ies (Russow 1880) is still used today, at least in spring (this study). The number of Taiga Bean Geese using this route is unknown, however, as is information on variation in numbers between seasons and years. It is also not known if all birds using this route make stop-overs. Thus, the count of 550 birds in spring 2013 should be regarded as a minimum for the study period. Two recoveries of marked birds, one in Estonia (Saurola et al. 2013) and one in Latvia (this study) link this migration route to the breeding range of the central sub-population, which is the most probable origin of the birds using the East Baltic Sea coastal route.

Presently, the Taiga Bean Geese staging in Latgale and Vidzeme are considered to belong to the eastern subpopulation (Marjakangas et al. 2015), partly due to the fact that all Taiga Bean Geese observed by the first author in these regions phenotypically were of that sub-population and partly due to a complete lack of recoveries and re- sightings of birds marked on the breeding grounds (this study). Similarly as for western Kurzeme, the number of birds migrating through Latgale and Vidzeme is unknown, as well as whether numbers differ between seasons and years, and if all birds migrating through Latgale and Vidzeme make stop-overs. For that reason, the count of 1750 birds in the spring of 2016 should be regarded as a minimum number for the study period. The reported flock size maximum at Lake Lubāns might be no coincidence, as the species apparently bred in the area in the early $19^{\text {th }}$ century (Plater 1852).

A very short duration of stay seems to be normal for Taiga Bean Geese in Latvia in spring (this study). However, due to lack of regular checks of the geese in most staging areas, it cannot be fully ruled out that some flocks make longer stop-overs.

Traditional monitoring based on mid-monthly counts (cf. Kampe-Persson 2014), had very likely missed almost all Taiga Bean Geese staging in Latvia in spring in 2011 - 2019. This is because the main arrival peak was in the last ten days of the month, February in western Kurzeme and March in Latgale and Vidzeme (this study), combined with apparent short duration of stay. A spring monitoring programme is needed, using the same methods as for the autumn monitoring programme initiated in Sweden by the first author (Kampe-Persson 2017).

The reported estimate of approximately 300 hunted Taiga Bean Geese annually in Latvia in the years 2008 - 2013 (Jānis Vỉksne, personal communication in Marjakangas et al. 2015) was clearly an overestimation due to lack of adequate data. The estimates of 0 to 20 birds hunted annually in the years $2014-2018$, on the other hand, agree with an almost complete lack of reports of staging Taiga Bean Geese in autumn. However, as also the reported numbers of staging Tundra Bean Geese in autumn have been quite low, this might be due to a low overall activity among bird-watchers in autumn.

Taiga and Tundra Bean Geese do not feed in mixed flocks when using the same staging area but divide up the feeding grounds (Kampe-Persson 2014 and unpublished results). The less numerous species uses a specific part of the staging area while the more numerous species uses the rest. Therefore, the fact that images of hunted bean geese were reported from almost all parts of the hunting grounds in Latvia does not necessarily mean that they represented all hunted flocks. There is no reason to believe that the distribution of feeding flocks has affected the estimates more than marginally however.

\section{Suggested monitoring and research activities}

More and better data are needed before Latvia can implement the national actions listed in the International Action Plan for the Taiga Bean Goose (Marjakangas et al. 2015). The following monitoring and research activities can form the basis for such actions. 
A national species-specific monitoring programme, based on regular counts throughout the spring staging period, should be initiated in Latvia. In that way, knowledge of the true number of staging Taiga Bean Geese and their duration of stay could be obtained.

Besides carefully counting the number of individuals in each staging flock, in spring as well as in autumn, the feeding sites should be mapped, the field type (food source) noted and, if possible, it should be established where the birds spend the night.

As a measure to establish the origin of birds migrating through Latvia, all staging Taiga Bean Geese should be carefully checked for the occurrence of neck collars and all spotted collars should be identified and duly reported. This should be combined with a call for hunters to report all marked geese they retrieve. The call should also include earlier retrieved but unreported individuals.

The bag study that started in 2014 should be continued. To ensure that the results reflect the true composition of the annual hunting bags, more hunters should be encouraged to submit images of the bean geese they have shot. At the same time as being a cheap method, results are obtained quickly, making it possible, if necessary, to take actions from one season to the next.

One action that can and should be taken already now is to raise awareness among bird-watchers and hunters of the actual situation for the Taiga Bean Goose. Birdwatchers should be urged to pay special attention to Taiga Bean Geese when watching staging geese and to report all observations of this taxon on www.dabasdati.lv. Hunters should continually be informed about the results of the ongoing bag study. The situation in Latvia should be set in an international context, giving examples of actions taken in other countries (cf. Heldbjerg et al. 2019).

\section{Acknowledgements}

Our thanks go to hunters who submitted images of shot bean geese, to bird-watchers who reported their observations by e-mail or by entering them on www.dabasdati.lv, to Leif Nilsson, Markus V Piha at the Bird Ringing Centre in Helsinki and an anonymous person at the Bird Ringing Centre in Moscow for mailing recoveries and re-sightings, to Valsts meža dienests (State Forest Service) for providing hunting statistics, to Aigars Kalvāns for preparing the figure and to an anonymous referee, whose comments helped to improve the presentation.

\section{References}

Fox A.D., Ebbinge B.S., Mitchell C., Heinicke T., Aarvak T., Colhourn K., Clausen P., Dereliev S., Faragó S., Koffijberg K., Kruckenberg H., Loonen M.J.J.E., Madsen J., Mooij J., Musil P., Nilsson L., Pihl S., van der Jeugd, H. 2010. Current estimates of goose population sizes in western Europe, a gap analysis and an assessment of trends. Ornis Svecica 20: 115-127.

Heinicke T. 2009. Status of the Bean Goose Anser fabalis wintering in central Asia. Wildfowl 59: 77-99.

Heldbjerg H., Fox A.D., Christersen T.K., Clausen P., KampePersson H., Koffijberg K., Liljebäck N., Mitchell C., Nilsson L., Skyllberg U., Alhainen M. 2019. Taiga Bean Goose population status report 2018-2019. Report prepared by the AEWA European Goose Management Platform (EGMP) Data Centre, $14 \mathrm{p}$.

Huyskens G. 1999. The Taiga Bean Goose (Anser fabalis): a species that needs world-wide protection. Georges Huyskens, Kapellen, Belgium, 77 p.

Kampe-Persson H. 2010a. Geese in Latvia - past, present and future. Goose Bulletin 10: 18-27.

Kampe-Persson H. 2010b. Naturalised geese in Europe. Ornis Svecica 20: 155-173.

Kampe-Persson H. 2014. Staging and wintering Taiga Bean Geese Anser fabalis fabalis in north-east Scania, south Sweden. Ornis Svecica 24: 56-78.

Kampe-Persson H. 2015. Swedish Lesser White-fronted Geese Anser erythropus in the Baltic States. Ornis Svecica 25: 67-69.

Kampe-Persson H. 2017. Höstinventering. [Autumn survey] Vår Fågelvärld 76: 38-40.

Marjakangas A., Alhainen M., Fox A.D., Heinicke T., Madsen J., Nilsson L., Rozenfeld S. (Compilers) 2015. International Single Species Action Plan for the Conservation of the Taiga Bean Goose Anser fabalis fabalis. AEWA Technical Series No. 56. Bonn, Germany, 99 p.

Nilsson L. 1982. Sädgåsens ruggning, flyttning och övervintring i Sverige. [Moult, migration and wintering in Sweden of the bean goose] In: Svensson S. (ed) De svenska gässen förekomst, ekologi, betesskador, jakt och vård [The Swedish geese - occurrence, ecology, crop damage, hunting and conservation] Vår Fågelvärld, Supplement No. 9. Sveriges Ornitologiska Förening, Stockholm, pp. 13-22.

Nilsson L. 2013. Staging and wintering goose populations in Sweden 1977/78-2011/12. Ornis Svecica 23: 3-45.

Nilsson L., van den Bergh L., Madsen J. 1999. Taiga Bean Goose Anser fabalis fabalis. In: Madsen J., Cracknell G., Fox A.D. (eds) Goose Populations of the Western Palearctic. Wetlands International Publication No. 48. Wetlands International \& National Environment Research Institute, Wageningen \& Rønde, pp. 20-36.

Plater A. 1852. Spis zwierząt ssących, ptaków i ryb krajowych, systematycznie ułoźony na oddziały, rzędy, pokrewieństwa, rodzaje i gatunki, przez. [The list of mammals, birds and fish of our country systematised into orders, families, genera and species] Józef Zawadzkiego, Vilnius, 160 p.

Russow V. 1880. Die Ornis Ehst-, Liv- und Curlands mit besonderer Berücksichtigung der Zug- und Brutverhältnisse. H. Laakmanns Buch- und Steindruckerei, Dorpat, Estonia, $216 \mathrm{p}$.

Saurola P., Valkama J., Velmala, W. 2013. The Finnish Bird Ringing Atlas. Vol. I. Finnish Museum of Natural History, Helsinki. (Finnish with English summary), 549 p.

von Essen L. 1982. Försöksverksamheten med uppfödning och utplantering av sädgås. [The experimental work of breeding and releasing bean goose.] In: Svensson S. (ed) De svenska gässen - förekomst, ekologi, betesskador, jakt och vård. [The Swedish geese - occurrence, ecology, crop damage, hunting and conservation] Vår Fågelvärld, Supplement No. 9. Sveriges Ornitologiska Förening, Stockholm, pp 105-108. 